\title{
Real-Time PCR using a PCR Microchip with Integrated Thermal System and Polymer Waveguides for the Detection of Campylobacter jejuni
}

\author{
Wang, Zhenyu; Sekulovic, Andrea; Kutter, Jörg Peter; Bang, D.D.; Wolff, Anders
}

Published in:

Proceedings of IEEE MEMS 2006

Link to article, DOI:

10.1109/MEMSYS.2006.1627856

Publication date:

2006

Document Version

Publisher's PDF, also known as Version of record

Link back to DTU Orbit

Citation (APA):

Wang, Z., Sekulovic, A., Kutter, J. P., Bang, D. D., \& Wolff, A. (2006). Real-Time PCR using a PCR Microchip with Integrated Thermal System and Polymer Waveguides for the Detection of Campylobacter jejuni. In Proceedings of IEEE MEMS 2006 (pp. 542-545). IEEE. https://doi.org/10.1109/MEMSYS.2006.1627856

\section{General rights}

Copyright and moral rights for the publications made accessible in the public portal are retained by the authors and/or other copyright owners and it is a condition of accessing publications that users recognise and abide by the legal requirements associated with these rights.

- Users may download and print one copy of any publication from the public portal for the purpose of private study or research.

- You may not further distribute the material or use it for any profit-making activity or commercial gain

- You may freely distribute the URL identifying the publication in the public portal 


\title{
REAl-TiMe PCR USING A PCR MiCROCHIP WITH INTEGRATEd THERMAL SYSTEM AND POLYMER WAVEguIDES FOR THE DETECTION OF CAMPYLOBACTER JEJUNI
}

\author{
Z. Wang ${ }^{1}$, A. Sekulovic ${ }^{1,2}$, J.P. Kutter ${ }^{1}$, D.D. Bang ${ }^{3}$ and A. Wolff \\ ${ }^{1}$ MIC - Department of Micro and Nanotechnology, Technical University of Denmark \\ ${ }^{2}$ Department of Biotechnology, Technical University of Delft \\ ${ }^{3}$ Department of Poultry, Fish and Fur Animals, Danish Institute for Food and Veterinary Research
}

\begin{abstract}
A novel real-time PCR microchip platform with integrated thermal system and polymer waveguides has been developed. By using the integrated optical system of the real-time PCR chip, cad $\mathrm{F}$ - a virulence gene of Campylobacter jejuni, could specifically be detected. Two different DNA binding dyes, SYTOX Orange and TO-PRO-3, were added to the PCR mixture to realize the real-time PCR. The presented approach shows reliable real-time quantitative information of the PCR amplification of the targeted gene.
\end{abstract}

\section{INTRODUCTION}

During the last decade, lab-on-a-chip devices have had a remarkable impact on biochemical, chemical, and pharmaceutical research activities, because of their reduced cost, portability, and low reagents consumption [1]. To realize such lab-on-a-chip systems, integration of different detectors to monitor various parameters within the system is a crucial step.

Polymerase Chain Reaction (PCR) is an enzymecatalyzed nucleotide amplification technique, routinely used in many different fields for genetic identification. Although PCR is a robust and predictable method, quantification can be difficult because the final amplified product concentration always has huge variations caused by minor disturbances, e.g. reaction components, thermal cycling fluctuation, or primer misalignment [2]. A solution to this problem is to use real-time PCR. In real-time PCR the product formation is measured during the reaction by using fluorescent DNA binding dyes or different types of probes that bind to the DNA targets. In this way, a PCR amplification curve can be visualized. Reading the cycle threshold $\left(\mathrm{C}_{\mathrm{T}}\right)$ value, i.e., the cycle number when the fluorescence intensity is higher than the detection baseline level, can provide more accurate and real-time quantitative information on the PCR amplification process [3]. Campylobacter jejuni is the most common foodborne bacterial pathogen that causes gastroenteritis for humans [4]. Several groups have developed a real-time PCR procedure for rapid detection of Campylobacter [5-7].

To date, three different types of PCR microchips have been developed, featuring a chamber [8], a continuous flow [9], and a droplet oscillation design [10], respectively. Previously, we reported on a PCR microchip with integrated thermal system for fast thermocycling [11]. Until now only few real-time PCR microsystems have been reported [12, 13]. In 2004, Gulliksen, A. et al. reported on a real-time PCR microchip using an external optical system to detect the fluorescent probes $[12,13]$.

Here, we present a novel real-time PCR microchip with integrated heater, thermometer and polymeric optical elements to detect DNA binding dyes. The chip was applied to amplify the cadF gene of Campylobacter jejuni. The PCR reaction dynamics could be monitored locally in real-time using the integrated waveguides.

\section{CHIP DESIGN, FABRICATION AND PACKAGING}

The fabrication of the real-time PCR microchip is a threemask process. Firstly, the electrodes $(100 \AA \mathrm{Ti}, 200 \mathrm{~nm} \mathrm{Pt})$ for the integrated heater array and thermometer were deposited on a $500 \mu \mathrm{m}$ Pyrex substrate by e-beam evaporation and defined in a standard lift-off process. Secondly, on top of the metal layer, a $5 \mu \mathrm{m}$ SU-8 protection layer was fabricated to serve as the chamber bottom. Finally, the $8 \mathrm{~mm} \times 8 \mathrm{~mm}$ reaction chamber $(25 \mu \mathrm{l})$ and optical systems were defined by standard photolithography in a 400 $\mu \mathrm{m}$ thick SU-8 layer (refractive index $\mathrm{n}=1.59$ ). The chip structure is shown in Fig. 1.

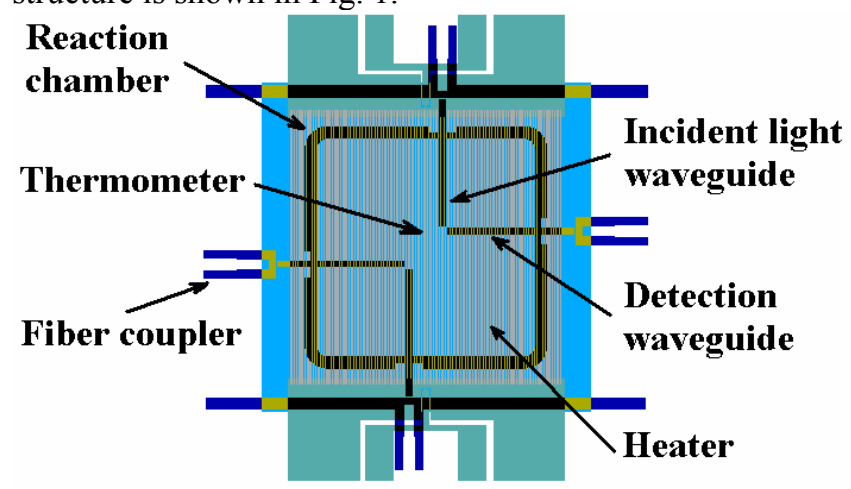

Figure 1. Schematics of the chip structure.

The reaction chamber was hermetically sealed by a 1 mm thick PDMS lid with a refractive index $n=1.4$, which also provides top cladding for the waveguides. The substrate $(n=1.46)$ provides the buffer layer of the waveguides, while the PCR mix $(\mathrm{n}=1.32)$ provides the vertical side claddings of the $200 \mu \mathrm{m}$ wide waveguides. The SU-8 layer thickness was adjusted to readily accommodate $400 \mu \mathrm{m}$ outer diameter optical fibers in the fiber couplers.

\section{RESULTS AND DISCUSSION}

Based on a previous integrated thermal system design [11], the Pt heater array was remodeled and redesigned. A 2D heat transport model has been established in FEMLAB 3.1 (Fig. 2 ). The heat is generated by the integrated Pt heater array. The chip is passively cooled by heat conduction through the substrate to a heatsink and by natural convection from the lid. There is extra heat loss from the edge of the chamber and to avoid the detrimental effect of a "cold wall", the integrated 
Pt heater array was designed to generate a 1.1 times higher heat density at the edges by reducing the heater width or the distance between the heaters, and extending the heaters outside of the chamber. The simulation results (Fig. 2) show a much better temperature profile for the non-uniform heat source than for the uniform one. The homogeneous temperature area (within $\pm 0.5^{\circ} \mathrm{C}$ variation at $94{ }^{\circ} \mathrm{C}$ ) inside the chamber has been expanded three times in comparison to the privious design [11], from $16 \mathrm{~mm}^{2}$ to $49 \mathrm{~mm}^{2}$. A Labview-based PID temperature-controlling program was used to control the integrated thermal system with a $15 \mathrm{~W}$ custom-built power supply.

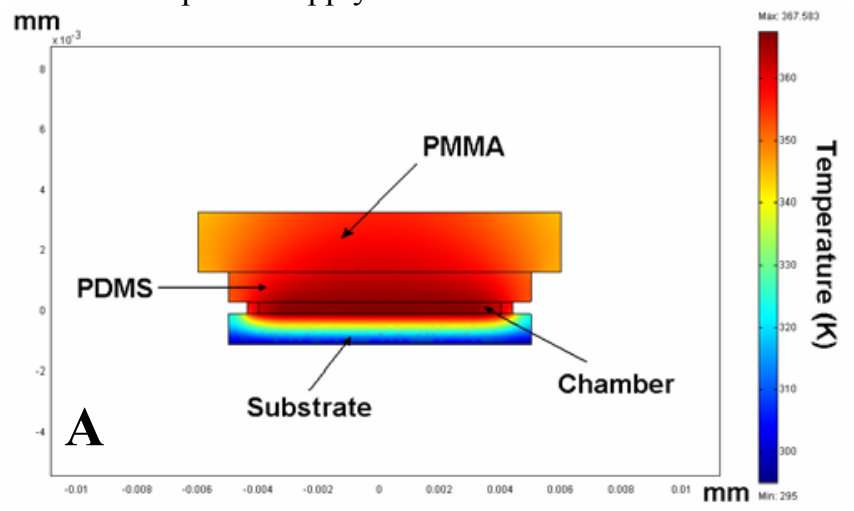

Effects of nonuniform heat source

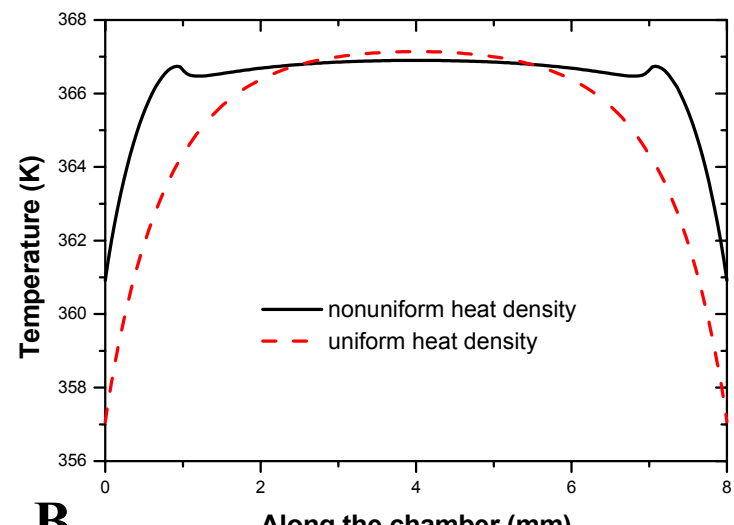

B

Along the chamber (mm)

Figure 2: A: The simulated thermal profile using a 2D heat transfer simulation model in FEMLAB3.1. B: Comparison of the temperature profile inside the reaction chamber for two different heat source designs.

On top of the integrated thermal system, a $25 \mu \mathrm{l}$ reaction chamber with integrated optics were defined in a $400 \mu \mathrm{m}$ thick SU-8 layer. Standard real-time PCR DNA binding dyes, such as SYBR ${ }^{\circledR}$ Green [15], have to be excited by a blue light source (e.g. Ar-ion laser: 488nm). To avoid the high propagation loss of SU-8 at lower wavelengths (less than $500 \mathrm{~nm}$ ) [14], two other dyes with higher excitation and emission wavelength were selected for the real-time PCR in this study: SYTOX Orange (ex 547nm/em 570nm) and TOPRO-3 (ex 642nm/em 661nm). A diode pumped solid state green laser $(535 \mathrm{~nm})$ and a He-Ne laser $(633 \mathrm{~nm})$ were used to provide two required different excitation wavelengths. To prevent fluorescence bleaching, the incident light was chopped at $1 \mathrm{~Hz}$ by a chopping blade (3\% duty cycle), then coupled into the optical fiber and integrated waveguides.

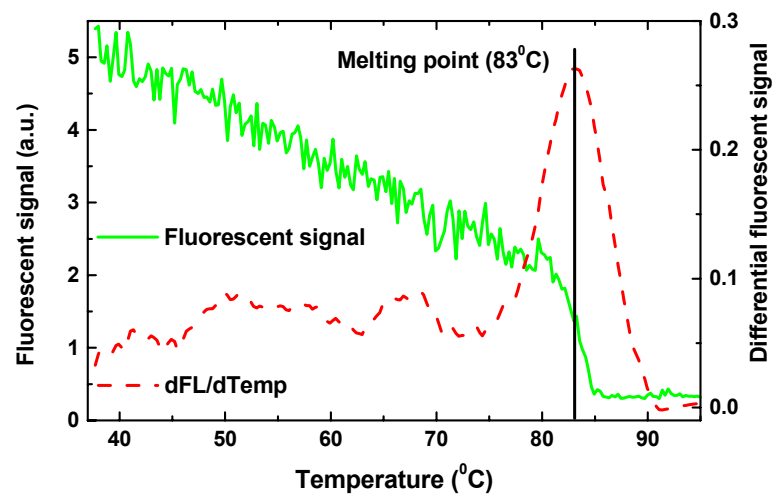

Figure 3. Melting curve measurement of the 398 bp amplicon of Campylobacter jejuni cadF gene using DNA binding SYTOX Orange dye.

On the real-time PCR microchip, the melting temperature of the DNA fragment could be determined with the DNA binding dyes during a temperature gradient run (Fig. 3). The DNA binding dyes are only fluorescent when bound to double strand DNA. Therefore, at the melting point of the DNA fragment, where the double strand DNA melts to single strand DNA, the fluorescent signal decreases significantly. The melting point can be calculated by differentiating the registered melting curve. The melting point $\left(83^{\circ} \mathrm{C}\right)$ measured on the real-time PCR chip is the same as measured on the Chromo4 ${ }^{\circledR}$ real-time PCR thermal cycler.

DNA binding dyes will bind to a double strand DNA of any PCR product formation, therefore specific fluorescence probes are normally required for a multiplex real-time PCR. However, the costs of the dyes (and sometimes also of the polymerase enzyme) are much cheaper than those of the probes, and the requirements for PCR protocol optimization are less. Furthermore, by measuring the melting curve after the real-time PCR, the PCR product can be examined in situ without further external assays (e.g. DNA gel electrophoresis), which is not possible when using fluorescence probes. Comparison of the two methods revealed that increasing the dye concentrations in the realtime PCR could easily enhance the fluorescent intensity signal output. In this study the DNA binding dyes are therefore selected as appropriate candidates for a preliminary real-time PCR microchip testing.

In our experiments, two differently colored dyes (SYTOX Orange and TO-PRO-3) were added into the PCR mixes to monitor the reactions on chip. A typical data profile of the real-time PCR is shown in Fig. 4. The three stages of a PCR cycle (15 seconds denaturation at $94{ }^{\circ} \mathrm{C}, 15$ seconds annealing at $50{ }^{\circ} \mathrm{C}$ and 15 seconds elongation at $72{ }^{\circ} \mathrm{C}$ ) can be clearly distinguished. Taking the mean fluorescent signal value during the annealing period of each thermal cycle, the relative PCR product concentration for each PCR cycle can be measured quantitatively. This short PCR thermocycling 
has been optimized by Poulsen et al. [16] in order to decrease the detection time. Due to the fast cooling $\left(20 \pm 2{ }^{\circ} \mathrm{C} / \mathrm{s}\right)$ and heating $\left(11 \pm 1{ }^{\circ} \mathrm{C} / \mathrm{s}\right)$ rate, the whole PCR process on chip only took $30-40$ minutes in comparison to one and a half hours on the conventional PCR. The short PCR thermal cycle also eliminates the increasing propagation loss effect of SU-8 waveguides under long-term exposure to $94{ }^{\circ} \mathrm{C}$.

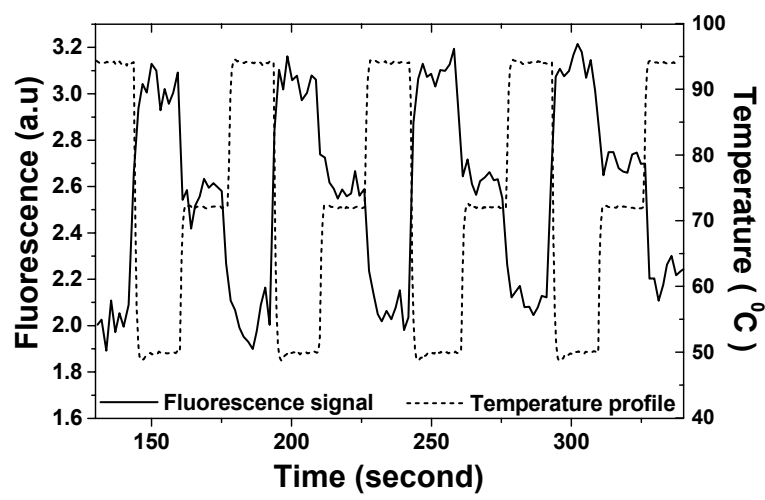

Figure 4. A typical real-time PCR on chip data profile. Due to the thermal dependence of the fluorescent dyes, the three stages of PCR can clearly be distinguished by fluorescence measurements using the integrated waveguides. The fluorescence signals exactly matched the measured temperature profile in the chip.

The surface inhibition of microfabricated PCR devices is always a critical issue for a successful PCR reaction on chip $[11,17,18]$. To avoid the inhibition of the SU-8 surface, 1 $\mu \mathrm{g} / \mu \mathrm{L}$ non-acetylated bovine serum albumin (BSA) was added to the PCR mix. An advantage of the BSA is the reagent does not add to the fluorescent background. The applied dye concentrations in the PCR mixture are optimized and limited at $200 \mathrm{nM}$ to avoid any reaction inhibition. Even so, the PCR product yields on chip were lower than the ones achieved by conventional PCR in tubes.

The results of real-time PCR on chip using SYTOX Orange to detect the Campylobacter jejuni cad $\mathrm{F}$ gene [4] for different DNA template concentrations (from 2 to 200 $\mathrm{ng} / \mathrm{mL}$ ) are shown in Fig. 5A. Results of gel electrophoresis for the PCR products both on chip and in tube, are shown in Fig. 5B. The size of the chamber is designed to be $25 \mu \mathrm{l}$ for easy collection of the PCR products for further assays (e.g. DNA capillary gel electrophoresis). The PCR cycle threshold $\left(\mathrm{C}_{\mathrm{T}}\right)$ values and the final PCR product concentrations for the different DNA template concentrations can be clearly determined from the real-time PCR profile and the DNA gel electrophoresis, respectively.

The $\mathrm{C}_{\mathrm{T}}$ value represents the cycle number when the PCR product concentration matches the detection baseline level, as shown in equation (1).

$$
\text { Conc }_{\text {baseline }}=\text { Conc }_{\text {template }} \times 2^{C_{T}}
$$

Since the baseline level is constant, the $C_{T}$ value should be proportional to the base two logarithm of the PCR template concentration.

$$
C_{T}=\log _{2}\left(\text { Conc }_{\text {baseline }}\right)-\log _{2}\left(\text { Conc }_{\text {template }}\right)
$$

Ideally, the final PCR product concentration should be proportional to the PCR template concentration, as shown in equation (3).

$$
\text { Conc }_{\text {product }}=\text { Conc }_{\text {template }} \times 2^{C_{\text {End }}}
$$

where $C_{E n d}$ is the total number of thermo cycles.

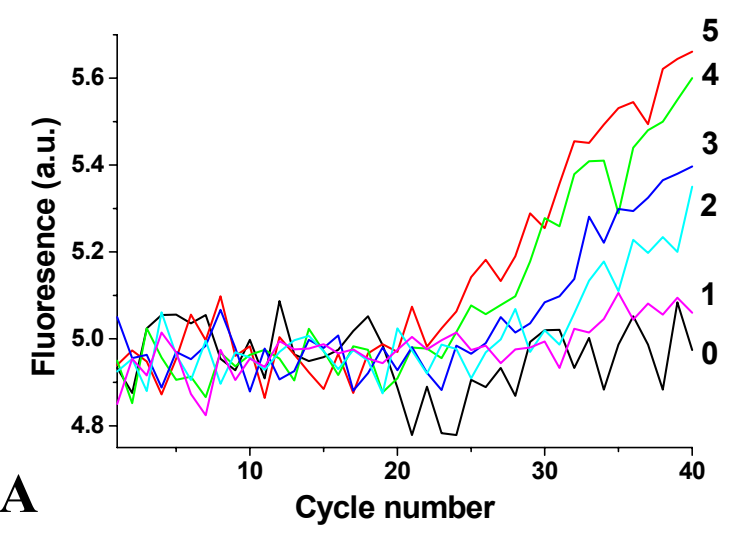

B

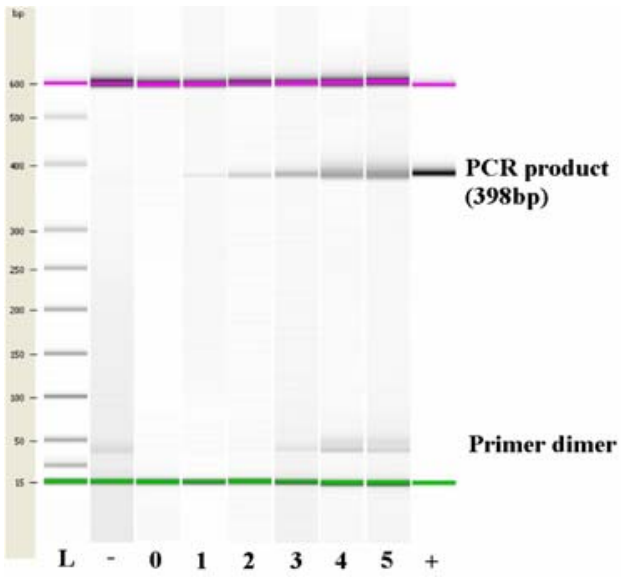

Figure 5. A: Real-time PCR on chip to amplify the 398bp amplicon on the Campylobacter jejuni cadF gene using DNA binding dyes. 0.: negative control on chip; 1-5.:real-time PCR on chip for detection the Campylobacter jejuni DNA template series, 100 fold template dilution series, from 2 to $200 \mathrm{ng} / \mathrm{mL}$; B: Results of capillary gel electrophoresis from Agilent Bioanalyzer DNA500 chip. L: DNA marker ladder (15-600bp); -.. negative control in tube; +.: positive control in tube.

Using the results obtained from the real-time PCR microchips, the logarithmic correlation between $\mathrm{C}_{\mathrm{T}}$ and DNA template concentration, and the linear correlation between PCR product concentration and DNA template concentration for both dyes are plotted in Fig. 6. The $C_{T}$ value measurements (Fig. 6A) provide more accurate information about the initial DNA template concentrations than the measurements of the final PCR product concentration (Fig. 6B). This results are in agreement with the literature $[2,3]$. The internal assays $\left(\mathrm{C}_{\mathrm{T}}\right)$ also clearly show that TO-PRO-3 inhibits the reaction more than SYTOX Orange under the same conditions. The external assays (DNA capillary gel electrophoresis) cannot reveal this fact. Hence, a reliable 
quantitative measurement of PCR amplification process can be achieved using the presented real-time PCR microchip.
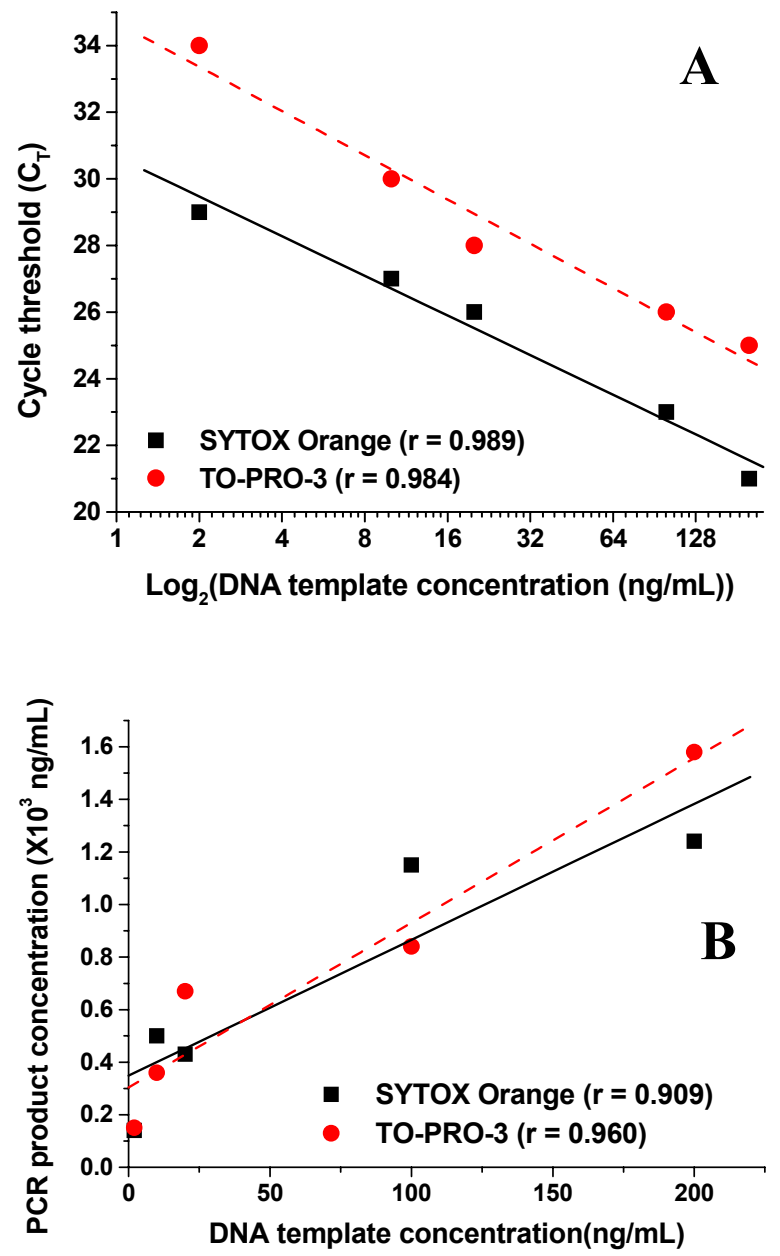

Figure 6. Two different excitation wavelengths DNA binding dyes (SYTOX Orange and TO-PRO-3) were used for detection of the Campylobacter jejuni cadF gene on the realtime PCR chip. A: The internal assays $\left(C_{T}\right)$ for both dyes show good linear relationships with the base two logarithm of the DNA template concentration series; B: The external assays (DNA gel electrophoresis) results only can indicate the trend of the DNA template concentrations.

\section{CONCLUSIONS}

In conclusion, to our knowledge this is the first time realtime PCR monitoring using integrated optical elements in a lab-on-a-chip system was demonstrated. The presented approach can efficiently provide the quantitative information of the amplified PCR progression. The integrated optical system allows real-time monitoring of the reaction dynamics at any location inside the micro reaction system.

\section{REFERENCES}

[1] D. Figeys, D. Pinto, "Lab-on-a-chip: A Revolution in Biological and Medical Sciences", Anal. Chem., vol. 72, pp. 330A-335A, 2000.

[2] J. Wilhelm, A. Pingoud, "Real-Time Polymerase Chain Reaction", Chembiochem, vol. 4, pp. 1120-1128, 2003.
[3] M.L. Wong, J.F. Medrano, "Real-Time PCR for mRNA Quantitation", Biotechniques, vol. 39, pp. 75-85, 2005.

[4] D.D. Bang, E.M. Nielsen, F. Scheutz, K. Pedersen, K. Handberg, M. Madsen, "PCR Detection of Seven Virulence and Toxin Genes of Campylobacter jejuni and Campylobacter coli Isolates from Danish Pigs and Cattle and Cytolethal Distending Toxin Production of The Isolates", J. Appl. Microbiol., vol. 94, pp. 1003-1014, 2003.

[5] E.L. Best, E.J. Powell, C. Swift, K.A. Grant, J.A. Frost, "Applicability of A Rapid Duplex Real-Time PCR Assay for Speciation of Campylobacter jejuni and Campylobacter coli Directly from Culture Plates", FEMS Microbiol. Lett., vol. 229, pp. 237-241, 2003.

[6] C. Yang, Y. Jiang, K. Huang, C. Zhu, Y. Yin, "Application of Real-Time PCR for Quantitative Detection of Campylobacter jejuni in Poultry, Milk and Environmental Water", FEMS Immunol. Med. Microbiol., vol. 38, pp. 265-271, 2003.

[7] M. Abu-Halaweh, J. Bates, B.K. Patel, "Rapid Detection and Differentiation of Pathogenic Campylobacter jejuni and Campylobacter coli by Real-Time PCR", Res. Microbiol., vol. 156, pp. 107-114, 2005.

[8] Y.C. Lin, C.C. Yang, M.Y. Huang, "Simulation and Experimental Validation of Micro Polymerase Chain Reaction Chips", Sens. Actuator B-Chem., vol. 71, pp. 127-133, 2000.

[9] I. Schneegaß, R. Bräutigam, J.M. Köhler, "Miniaturized FlowThrough PCR with Different Template Types in A Silicon Chip Thermocycler", Lab Chip, vol. 1, pp. 42-49, 2001.

[10] W. Wang, Z.-X. Li, R. Luo, S.-H. Lu, A.-D. Xu, Y.-J. Yang, "Droplet-Based Micro Oscillating-Flow PCR Chip", J. Micromech. Microeng., vol. 15, pp. 1369-1377, 2005.

[11] J. El-Ali, I.R. Perch-Nielsen, C.R. Poulsen, D.D. Bang, P. Telleman, A. Wolff, "Simulation and Experimental Validation of A SU-8 based PCR Thermocycler Chip with Integrated Heaters and Temperature Sensor", Sens. Actuator A-Phys., vol. 110, pp. 3-10, 2004.

[12] A. Gulliksen, L. Solli, F. Karlsen, H. Rogne, E. Hovig, T. Nordstrom, R. Sirevag, "Real-Time Nucleic Acid SequenceBased Amplification in Nanoliter Volumes", Anal. Chem., vol. 76, pp. 9-14, 2004.

[13] A. Gulliksen, L.A. Solli, K.S. Drese, O. Sorensen, F. Karlsen, H. Rogne, E. Hovig, R. Sirevag, "Parallel Nanoliter Detection of Cancer Markers using Polymer Microchips", Lab Chip, vol. 5, pp. 416-420, 2005.

[14] K.B. Mogensen, J. El-Ali, A. Wolff, J.P. Kutter, "Integration of Polymer Waveguides for Optical Detection in Microfabricated Chemical Analysis Systems", Appl. Optics, vol. 42, pp. 4072-4079, 2003.

[15] P.T. Monis, S. Giglio, C.P. Saint, "Comparison of SYTO9 and SYBR Green I for Real-Time Polymerase Chain Reaction and Investigation of The Effect of Dye Concentration on Amplification and DNA Melting Curve Analysis", Anal. Biochem., vol. 340, pp. 24-34, 2005.

[16] C.R. Poulsen, J. El-Ali, I.R. Perch-Nielsen, D.D. Bang, A. Wolff, "Detection of A Putative Virulence cadF Gene of Campylobacter jejuni Isolates from Different Sources using A Microfabricated PCR Chip", J. Rapid Methods Autom. Microbiol., vol. 13, pp. 111-126, 2005.

[17] Y.S. Shin, K. Cho, S.H. Lim, S. Chung, S.-J. Park, C. Chung, D.-C. Han, J.K. Chang, "PDMS-Based Micro PCR Chip with Parylene Coating", J. Micromech. Microeng., vol. 13, pp. 768774, 2003.

[18] J. Felbel, I. Bieber, J. Pipper, J.M. Kohler, "Investigations on The Compatibility of Chemically Oxidized Silicon ( $\mathrm{SiOx}$ )Surfaces for Applications Towards Chip-Based Polymerase Chain Reaction", Chem. Eng. J., vol. 101, pp. 333-338, 2004. 